\title{
Efektivitas Instrumen Penilaian Kinerja Siswa Berbasis Masalah dalam Mata Pelajaran Sosiologi
}

\author{
Widia Rahmi ${ }^{1}$, Ike Sylvia ${ }^{2}$ \\ ${ }_{1,2}^{1}$ Universitas Negeri Padang \\ Email: widiarahmi10@gmail.com, ikesylvia@fis.unp.ac.id
}

\begin{abstract}
Abstrak
Penelitian ini bertujuan untuk mengetahui keefektifan instrumen penilaian kinerja pada mata pelajaran sosiologi kelas XI IPS SMA N 2 Lubuk Sikaping untuk mengukur keterampilan peserta didik. Jenis penelitian ini adalah eksperimen dengan menggunakan desain one shot cased study. Teknik pengumpulan data menggunakan instrumen penilaian kinerja yang telah dikembangkan dan dinyatakan layak untuk diujicobakan oleh ahli. Jumlah sampel pada penelitian ini adalah 30 orang siswa. Teknik analisa data mengganakan analisis persentase dan membandingkan skor penilaian kinerja siswa dengan acuan penilaian keterampilan sesuai panduan penilaian kurikulum 2013. Instrumen penilaian kinerja yang telah dikembangkan meliputi aspek pengumpulan data, analisis data dan komunikasi. Hasil uji efektifitas memperlihatkan 2 orang siswa memperoleh skor penilaian keterampilan dengan predikat A (5\%), 23 orang dengan predikat B $(77 \%)$ dan 5 orang $(17 \%)$ dengan predikat C. Hasil ini memperlihatkan instrumen penilaian kinerja efektif mengukur keteampilan siswa khusunya dalam melakukan penelitian dan mempresentasikan penelitian pada materi konflik sosial.
\end{abstract}

Kata kunci: Instrumen Penilaian Kinerja, Penilaian Keterampilan, Pembelajaran Sosiologi

\section{Abstract}

This study aims to determine the effectiveness of the performance assessment instrument on sociology subjects in class XI IPS SMA N 2 Lubuk Attitude to measure students' skills. This type of research is an experiment using one shot cased study design. The data collection technique uses a performance appraisal instrument that has been developed and declared feasible to be tested by experts. The number of samples in this study were 30 students. The data analysis technique uses percentage analysis and compares student performance assessment scores with a skill assessment reference according to the 2013 curriculum assessment guide. The performance assessment instruments that have been developed include aspects of data collection, data analysis and communication. The results of the effectiveness test showed that 2 students obtained a skill assessment score with a predicate of $A(5 \%), 23$ people with a predicate of $B(77 \%)$ and 5 people (17\%) with a predicate of $C$. These results show that the performance assessment instrument is effective in measuring students' skills, especially in conducting research and presenting research on social conflict material.

Keywords: Performance Assessment Instruments, Skills Assessment, Sociology Learning

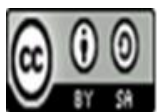

\begin{tabular}{l|l|l} 
Received: May 2, 2021 & Revised: June 8, 2021 & Accepted: June 9, 2021
\end{tabular} 


\section{Pendahuluan}

Sosiologi adalah salah satu mata pelajaran di SMA yang dibelajarkan bagi siswa khusunya peminatan ilmu-ilmu sosial. Menurut Selo Soemardjan dan Soelaeman menyatakan bahwa sosiologi ialah ilmu yang mengkaji struktur sosial dan proses-proses sosial, termasuk perubahanperubahan sosial (Soerjono, 2013). Berdasarkan kurikulum 2013 pembelajaran sosiologi lebih menekankan praktik pengetahuan sosiologi dari pada sosiologi sebagai pengetahuan semata, dalam praktiknya pembelajaran itu dijalankan dengan tekanan yang berbeda-beda untuk tiap jenjang atau masing-masing kelas, pada kelas XI menekankan pada praktik pemecahan masalah sosial. Jadi pada kelas XI siswa diharapkan mampu melakukan pemecahan masalah dalam pembelajaran. Pembelajaran pada hakikatnya adalah suatu proses, yaitu proses mengatur, mengorganisasi lingkungan yang ada di sekitar peserta didik sehingga dapat menumbuhkan dan mendorong peserta didik melakukan proses belajar. Pembelajaran juga dikatakan sebagai proses memberikan bimbingan atau bantuan kepada siswa dalam melakukan proses belajar (Pane \& Darwis Dasopang, 2017). Pembelajaran sosiologi adalah proses memfasilitasi peserta didik agar dapat memperoleh pemahaman, pengertian, ilmu dan sikap tentang hubungan manusia dengan masyarakat. Untuk mengetahui tercapai atau tidaknya tujuan pembelajaran maka perlu dilakukan penilaian. Penilaian merupakan hal yang sangat penting dalam sebuah pembelajaran karena dengan penilaian kita dapat melihat bagaimana kualitas pendidikan dan dapat melakukan suatu perubahan. Bagi siswa sendiri, sistem penilaian yang baik akan mampu memberikan motivasi untuk selalu meningkatkan kemampuannya. Oleh karena itu, penilaian sangat penting untuk dilakukan (Basri, Syamsudduha, \& Taufiq, 2017). Penilaian adalah suatu proses atau kegiatan yang sistematis dan berkesinambungan untuk mengumpulkan informasi tentang proses dan hasil belajar peserta didik dalam rangka membuat keputusan-keputusan berdasarkan ktiteria dan penilaian tertentu, contoh keputusan adalah nilai yang diberikan, keputusan naik kelas dan kelulusan (Arifin, 2009). Penilaian yang dilakukan saat ini sesuai dengan kurikulum yang berlaku, pada saat ini kurikulum yang dipakai adalah kurikulum 2013 yang mengacu pada Permendikbud Nomor 23 tahun 2020 tentang standar penilaian pendidikan, ruang lingkup penilaian kurikulum 2013 adalah mencakup kompetensi sikap, pengetahuan, dan keterampilan peserta didik yang dilakukan secara berimbang sehingga dapat digunakan untuk menentukan posisi relatif setiap siswa terhadap standar yang telah ditetapkan (Kemendikbud, 2020).

Prosedur dan alat untuk evaluasi kompetensi sikap, informasi dan kemampuan yaitu: 1) Evaluasi kompetensi sikap: Instruktur mengarahkan evaluasi kompetensi disposisi melalui persepsi, evaluasi diri, penilaian sejawat oleh siswa dan buku harian dengan instrumen agenda atau skala penilaian yang digabungkan dengan rubrik, sedangkan diari sebagai catatan instruktur. 2) Evaluasi Kompetensi Informasi: Guru mensurvei kemampuan informasi melalui tes tersusun, tes lisan, dan tugas, a) Sebuah instrumen tes disusun sebagai pertanyaan keputusan yang berbeda, bagian, jawaban singkat, konsisten dan palsu, perjodohan, dan penggambaran. Instrumen penggambaran dilengkapi dengan aturan penilaian, b) Instrumen tes lisan adalah daftar pertanyaan, c) Instrumen tugas berupa tugas sekolah atau kegiatan yang dikerjakan secara eksklusif atau berkelompok yang ditunjukkan dengan atribut tugas. 3) Evaluasi kompetensi kemampuan: Instruktur mensurvei kemampuan keterampilan melalui ujian pelaksanaan, menjadi penilaian khusus yang mengharapkan siswa untuk menunjukkan kemampuan tertentu menggunakan tes yang layak, kegiatan, dan penilaian portofolio. Instrumen yang digunakan dalam evaluasi kompetensi keterampilan adalah a) skala penyusunan atau evaluasi yang dilengkapi dengan rubrik. Sebuah tes praktik adalah penilaian yang meminta reaksi sebagai kemampuan untuk melakukan tindakan atau perilaku sesuai permintaan kompetensi, b) Ventures adalah usaha pembelajaran yang menggabungkan latihan perencanaan, pelaksanaan dan perincian yang direkam sebagai hard copy atau secara lisan dalam waktu tertentu, c) Evaluasi portofolio adalah evaluasi yang dilakukan dengan mempelajari berbagai macam siswa di bidang tertentu yang bersifat Integratif cerdas untuk menemukan minat, peningkatan, prestasi, dan/atau 
kreativitas siswa dalam jangka waktu tertentu. Pekerjaan bisa menjadi kegiatan padat yang mencerminkan kepedulian siswa terhadap lingkungannya.(Kemendikbud, 2013). Seluruh aspek kompetensi dalam kurikulum 2013 memiliki macam-macam instrumen untuk macam-macam kompetensi yang akan diukur.

Pembelajaran sosiologi padas masa pandemi covid-19 di SMA N 2 Lubuk Sikaping dilakukan secara tatap muka namun dengan sistem paket. dibagi menjadi 2 paket yaitu siswa paket A siswa dan paket B dengan jumlah siswa sebanyak 15 orang untuk setiap paketnya. Melalui hasil observasi dan wawancara dengan guru sosiologi ibu YF pada tanggal 9 Februari 2021 dapat disimpulkan pembelajaran sosiologi dilakukan dengan metode ceramah dan penugasan, beberapa penugasan yang diberikan kepada siswa dapat meningkatkan keterampilan siswa namun guru hanya melakukan penilaian untuk aspek kognitif sedangkan format pelaporan penilaian tetap harus mencakup aspek afektif, kognitif dan psikomotor peserta didik. Penilaian pada aspek afektif sudah dilakukan oleh wali kelas dan guru BK sedangkan keterampilan harus dilakukan guru bidang studi. Pada proses penilaian keterampilan guru memberikan penugasan kepada peserta didik untuk melatih berkembangnya kompetensi keterampilan mereka, misalnya dengan membuat video pembelajaran, mempresentasikannya, dan lain lain. Namun pada proses penilaiannya guru menggabungkan produk keterampilan peserta didik pada ranah penilaian pengetahuan. Setalah peneliti dalami lebih lanjut, hali ini terjadi karena guru tidak memiliki instrument penilaian untuk mengukur keterampilan peserta didik. Untuk itu peneliti memandang perlu mengembangkan instrumen penilaian kompetensi keterampilan peserta didik. Oleh karena itu peneliti mengembangkan instrumen penilaian keterampilan peserta didik dan melakukan ujicobanya untuk melihat efektifitas instrumen keterampilan ini. mengembangkan instrumen penilaian kinerja siswa untuk mengukur keterampilan siswa.

Adapun instrumen keterampilan yang menjadi fokus penelitian ini adalah instrumen penilaian kinerja. Instrumen penilaian kinerja/unjuk kerja adalah instrumen yang mampu mengukur tindakan, kinerja atau tes praktik yang secara efektif dapat digunakan untuk kepentingan pengumpulan berbagai informasi tentang bentuk-bentuk perilaku atau keterampilan yang diharapkan muncul dalam diri peserta didik. Penilaian kinerja dilakukan dengan mengamati kegiatan peserta didik dalam melakukan sesuatu. Penilaian kinerja merupakan penilaian yang meminta peserta didik untuk mendemonstrasikan dan mengaplikasikan pengetahuan ke dalam konteks yang sesuai dengan kriteria yang ditetapkan (Kunandar, 2014) Penilaian kinerja digunakan untuk menilai kemampuan siswa melalui penugasan. Penugasan tersebut dirancang khusus untuk menghasilkan respon (lisan atau tulis), menghasilkan karya (produk), atau menunjukkan penerapan pengetahuan. Tugas yang diberikan kepada siswa harus sesuai dengan kompetensi yang ingin dicapai dan bermakna bagi siswa (Setyono, 2005).

Pada penelitian ini, peneliti mengembangkan instrumen penilaian kinerja berbasis penugasan menyelesaikan masalah. Adapun model pembelajaran yang digunakan sebagai acuan pelaksanaan pembelajaran adalah model problem based learning yaitu model pembelajaran yang mengembangakan keterampilan berpikir siswa dalam memecahkan masalah (Nuareni, 2016).

\section{Metode Penelitian}

Penelitian ini berjenis kuantitatif dengan jenis eksperimen. Desain eksperimen adalah One Shot Case Study. Penelitian ini khusus mengujicobakan instrumen penilaian kinerja yang telah dikembangkan dan dinyatakan valid oleh ahli. Proses uji coba instrumen penilaian kinerja ini dilakukan pada pembelajaran sosiologi SMA kelas XI materi konflik sosial. Tujuan proses uji coba instrumen ini untuk melihat efektifitas instrumen tersebut digunakan dan melihat dampaknya terhadap penilaian keterampilan siswa.

Pembelajaran diukur setelah perlakuan. Dengan demikian hasil perlakuan bisa dikenal lebih akurat sebab bisa menyamakan dengan kondisi saat sebelum diberi perlakuan (Sugiyono, 2017). Pendekatan ini dipilih untuk mengetahui pengaruh instrumen penilaian kinerja yang telah

Jurnal Sikola: Jurnal Kajian Pendidikan dan Pembelajaran Vol. 2, No. 4, Th. 2021 
dirancang terhadap skor ketrampilah siswa dalam pembelajaran sosiologi. Pembelajaran sosiologi dilakukan dengan mengikuti langkah-langkah model problem based learning dengan memberikan LKPD yang sesuai dan penugasan yang dapat melatih kinerja siswa khusunya membahas materi upaya penyelesaian konflik sosial. seiring dan penugasan yang sesuai rancangan instrumen penilaian kinerja dan setelah dilakukan pembelajaran. Penelitian ini diujicobakan pada kelas XI IPS 3 di SMAN 2 Lubuk Sikaping dengan jumlah siswa sebanyak 30 orang. Teknik pengumpulan data menggunakan instrumen penilaian kinerja. Teknik analisa data mengganakan analisis persentase dan membandingkan skor penilaian kinerja siswa dengan acuan predikat interval sebagai berikut:

\section{Tabel 1. Interval Predikat}

\begin{tabular}{cccc}
\hline \multicolumn{4}{c}{ Predikat } \\
\hline $\mathrm{D}$ & $\mathrm{C}$ & $\mathrm{B}$ & $\mathrm{A}$ \\
\hline$\leq 55$ & $55<\mathrm{N}<70$ & $70 \leq \mathrm{N}<85$ & $85 \leq \mathrm{N} \leq 100$ \\
\hline & & (Hamid, 2017)
\end{tabular}

\section{Hasil dan Pembahasan}

\section{Pelaksanaan Pembelajaran}

Pada penelitian ini, pembelajaran sosiologi kelas XI IPS 3 materi konflik sosial di SMAN 2 Lubuk Sikaping dibelajarkan dengan model problem based learning. Adapun proses pembelajaran yang dilakukan mengikuti sintak model problem based learning. Proses ujicoba instrumen kinerja ini dilakukan pada pertemuan ke 4 dari 4 kali pertemuan yang dilaksanakan sesuai RPP untuk materi konflik sosial di masyarakat hingga upaya penyelesaiannya.

Pada pertemuan pertama, guru memberikan orientasi siswa pada masalah, dengan cara menampilkan sebuah video pemberitaan konflik sosial dari youtube, kemudian meminta siswa untuk mengamati video tersebut. Kemudian guru juga memberikan sumber belajar kepada siswa mengenai metode penyelesaian konflik sosial. Setelah itu guru melakukan tanya jawab dengan siswa sehubungan dengan upaya konflik apa yang cocok dilakukan sehubungan dengan kasus tersebut. Pada pertemuan ini fokus pembelajaran agar siswa memahami beberapa metode penyelesaian konflik sosial.

Pada pertemuan kedua, guru melaksanakan sintak mengorganisasikan siswa untuk belajar, dengan cara memberikan kesempatan kepada siswa untuk membaca berbagai kasus konflik sosial yang telah terjadi melalui link pemberitaan online yang dibagikan guru kepada siswa. Selanjutnya guru memberi kesempatan kepada siswa untuk memilih salah satu kasus konflik sosial dan mengisi LKPD mereka. Pada LKPD yang telah dirancang oleh guru, siswa diminta untuk menganalisis kasus konflik sosial dan memilih salah satu upaya penyelesaian konflik sosial yang cocok sesuai dengan kasus yang dipilihnya, serta memberikan argumentasi mereka. Kemudian siswa diminta untuk mengembangkan dan menyajikan hasil karyanya dengan cara melakukan penelitian dokumentasi terkait kasus yang mereka pilih dan alternatif penyelesaian konflik yang dianggap tepat. Pada pertemuan ini guru menjalankan tugasnya sebagai fasilitator, memastikan siswa daapt menganalisis kasus yang dipilih dan mampu mengerjakan LKPD. Membimbing siswa agar mampu memahami langkah-langkah pengumpulan data penelitian yang mereka lakukan yaitu mencari dan menuliskan informasi dari buku, bahan ajar, LKS, sumber literasi lainnya untuk menguatkan pembahsaan yang sesuai dengan analisis kasus dan upaya penyelesaian konfliknya. Guru juga memastikan siswa mampu menyelesaiakn tahapan penelitian hingga dapat memperoleh data yang sesuai.

Pertemuan ketiga, langkah dari model problem based learning adalah melakukan pembimbingan dan menyajikan hasil karya. Guru membimbing siswa agar mampu menyusun temuan siswa, melakukan analisis dan membuat laporan penelitian. Laporan penelitian sederhana 
ini memuat format pendahuluan, hasil dan pembahasan, penutup serta sumber referensi. Guru memberitahukan kepada siswa untuk membawa laporan penelitian pada pertemuan berikutnya.

Pada pertemuan keempat, langkah dari model problem based learning adalah menganalsis dan mengevaluasi proses pemecahan masalah. Pada pertemuan ini guru menjelaskan tata cara presentasi, menyajikan presentasi dan memberikan masukan kepada hasil presentasi siwa lainnya. Siswa melakukan presentasi hasil penelitiannya dan guru melakukan penilaian kinerka menggunakan instrumen penilaian kinerja yang telah dirancang.

\section{Instrumen Penilaian Kinerja untuk Mengukur Keterampilan Siswa pada pembelajaran Sosiologi Kelas $X I$} ahli.

Berikut ini kisi-kisi instrumen penilaian kinerja yang telah dikembangkan dan divalidasi oleh

\section{Tabel 2. Kisi-kisi dan Rubrik Instrumen Penilaian Kinerja}

\begin{tabular}{|c|c|c|c|}
\hline Aspek keterampilan & Kriteria & Skor & Indikator \\
\hline \multirow[t]{8}{*}{ Pengumpulan Data } & \multirow[t]{4}{*}{ Kasus } & 4 & $\begin{array}{l}\text { Memilih kasus konflik sosial yang baru terjadi dan } \\
\text { belum selesai. }\end{array}$ \\
\hline & & 3 & $\begin{array}{l}\text { Memilih kasus konflik sosial yang baru terjadi tetapi } \\
\text { sudah selesai. }\end{array}$ \\
\hline & & 2 & $\begin{array}{l}\text { Memilih konflik sosial yang sudah lama terjadi tetapi } \\
\text { belum selesai. }\end{array}$ \\
\hline & & 1 & $\begin{array}{l}\text { Memilih kasus konflik sosial yang sudah lama terjadi } \\
\text { dan sudah selesai. }\end{array}$ \\
\hline & \multirow[t]{4}{*}{ Sumber } & 4 & $\begin{array}{l}\text { Memiliki } 3 \text { sumber dari media pemberitaan online } \\
\text { dengan jelas. }\end{array}$ \\
\hline & & 3 & Memiliki 2 sumber media pemberitaan dengan jelas. \\
\hline & & 2 & $\begin{array}{l}\text { Memiliki } 1 \text { sumber media pemberitaan online dengan } \\
\text { jelas. }\end{array}$ \\
\hline & & 1 & $\begin{array}{l}\text { Memiliki } 3 \text { sumber media pemberitaan tetapi tidak } \\
\text { jelas. }\end{array}$ \\
\hline \multirow[t]{8}{*}{$\begin{array}{l}\text { Analisis } \\
\text { Data }\end{array}$} & \multirow[t]{4}{*}{ Solusi } & 4 & $\begin{array}{l}\text { Menentukan upaya penyelesaian konflik sosial dengan } \\
\text { sangat tepat }\end{array}$ \\
\hline & & 3 & $\begin{array}{l}\text { Menentukan upaya penyelesaian konflik sosial yang } \\
\text { dengan tepat }\end{array}$ \\
\hline & & 2 & $\begin{array}{l}\text { Menentukan upaya penyelesaian konflik sosial yang } \\
\text { dengan cukup tepat }\end{array}$ \\
\hline & & 1 & $\begin{array}{l}\text { Menentukan upaya penyelesaian konflik sosial yang } \\
\text { dengan kurang tepat }\end{array}$ \\
\hline & \multirow[t]{4}{*}{ Kesimpulan } & 4 & $\begin{array}{l}\text { Menyimpulkan upaya penyelesaian konflik yang cocok } \\
\text { digunakan dengan sangat baik }\end{array}$ \\
\hline & & 3 & $\begin{array}{l}\text { Menyimpulkan upaya penyelesaian konflik yang cocok } \\
\text { digunakan dengan baik }\end{array}$ \\
\hline & & 2 & $\begin{array}{l}\text { Menyimpulkan upaya penyelesaian konflik yang cocok } \\
\text { digunakan dengan cukup baik }\end{array}$ \\
\hline & & 1 & $\begin{array}{l}\text { Menyimpulkan upaya penyelesaian konflik yang cocok } \\
\text { digunakan dengan kurang baik }\end{array}$ \\
\hline \multirow[t]{6}{*}{ Komunikasi } & \multirow[t]{4}{*}{ Deskripsi } & 4 & Mempresentasikan dengan sangat baik. \\
\hline & & 3 & Mempresentasikan dengan baik. \\
\hline & & 2 & Mempresentasikan dengan cukup baik. \\
\hline & & 1 & Mempresentasikan dengan kurang baik. \\
\hline & \multirow[t]{2}{*}{ Data } & 4 & Memiliki data yang sangat lengkap. \\
\hline & & 3 & Memiliki data yang lengkap. \\
\hline
\end{tabular}




$\begin{array}{ll}2 & \text { Memiliki data yang cukup lengkap. } \\ 1 & \text { Memiliki data yang kurang lengkap. }\end{array}$

Kisi-kisi dan rubrik instrumen penilaian kinerja di atas dirancang sesuai dengan RPP dan LKPD yang terdiri dari berbagai aspek keterampilan yang dimulai dari pengumpulan data, analisis data, dan komunikasi. Pada aspek keterampilan pengumpulan data terbagi menjadi dua kiteria yaitu kasus dan sumber karena guru akan menilai kasus yang dipilih siswa dari beberapa contoh kasus yang disediakan melalui link pemberitaan online mengenai materi konflik sosial. Kasus yang dianggap baik dan memiliki skor tertinggi adalah kasus yang baru terjadi dan belum selesai karena apabila siswa memilih kasus yang baru terjadi rasa keingintahuan lebih terhadap kasus konflik dan akan membawa dampak siswa ingin mencari banyak sumber informasi sehingga pengetahuan siswa bertambah, sedangkan sumber yang memiliki skor tertinggi adalah 3 sumber dari media pemberitaan dengan jelas. Aspek keterampilan yang kedua adalah analisis data dengan kriteria solusi dan kesimpulan, sesuai dengan indikator pembelajaran siswa bisa menentukan upaya penyelesaian konflik dengan tepat dan menyimpulkan upaya penyelesaian konflik sosial dengan jelas. Sedangkan aspek keterampilan yang terakhir adalah komunikasi, pada tahap ini siswa mempresentasikan laporan penelitiannya dengan sangat baik dan memiliki data dengan sangat lengkap. Setelah menentukan kisi-kisi dan rubrik instrumen penilaian kinerja selanjutnya peneliti merancang instrumen penilaian kinerja pada materi konflik sosial.

\section{Gambar 1. Rancangan Instrumen Penilaian Kinerja}

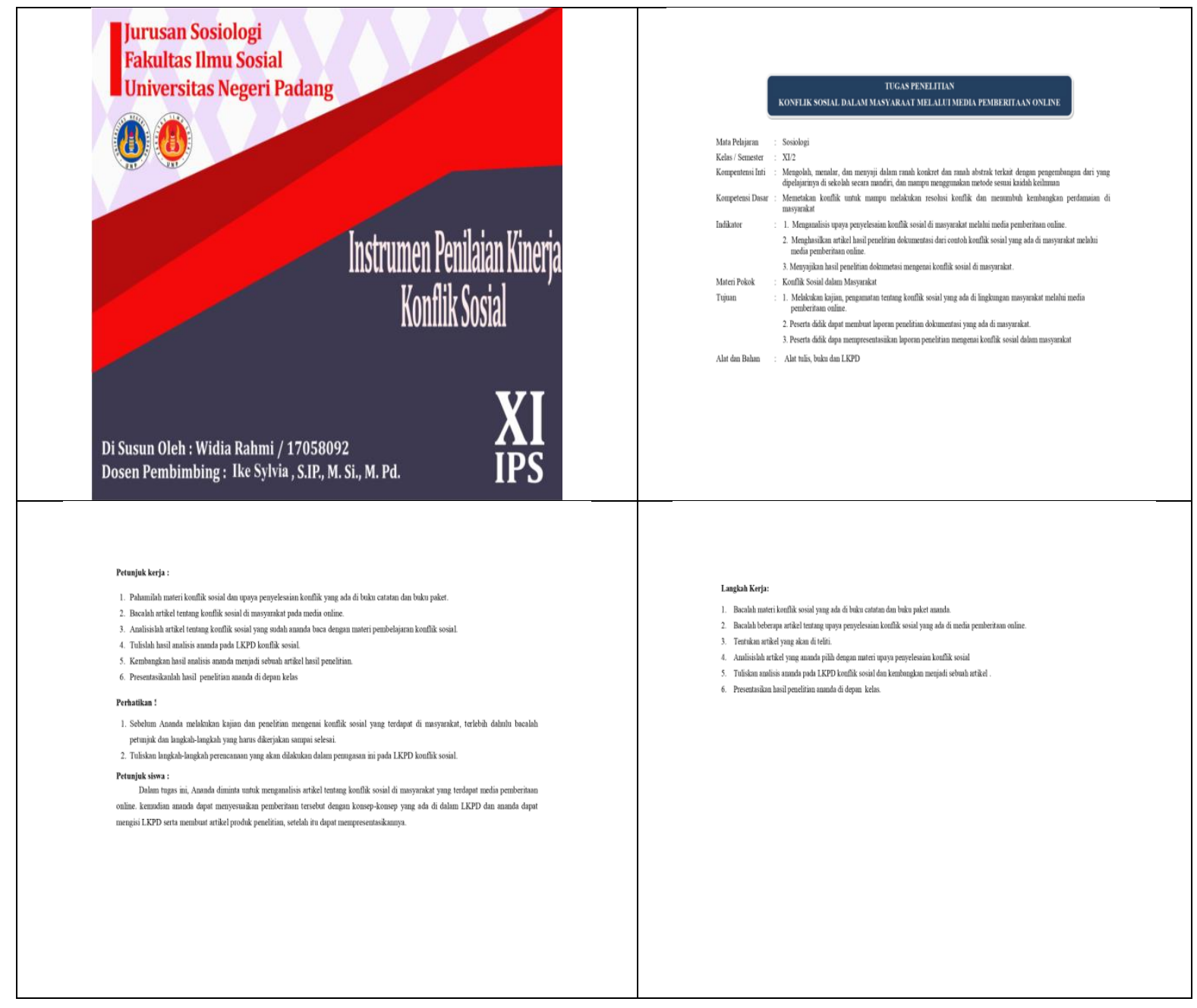

Jurnal Sikola: Jurnal Kajian Pendidikan dan Pembelajaran Vol. 2, No. 4, Th. 2021 


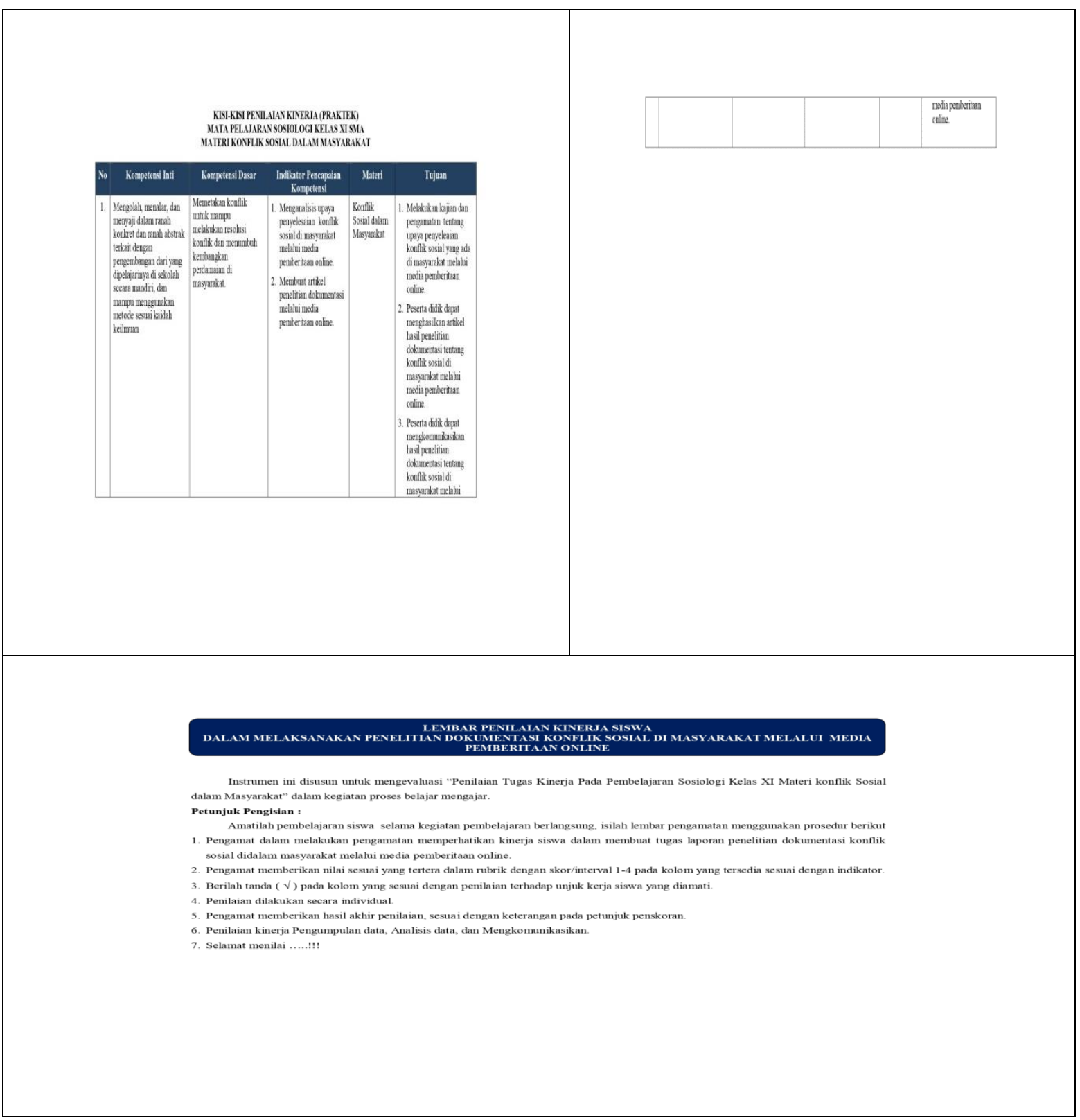

Rancagan instrumen penilaian kinerja terdiri dari cover, tugas penelitian yang disesuaikan dengan kompetensi inti dan kompetensi dasar, selanjutnya petunjuk kerja, langkah kerja, kisi-kisi instrumen penilaian kinerja, lembar penilaian yang terdiri dari petunjuk pengisian, dan rekap hasil kinerja siswa. Instrumen penilaian kinerja ini telah divalidasi oleh ahli dan layak diujicobakan.

\section{Uji Efektivitas Instrumen Penilaian Kinerja untuk Mengukur Keterampilan Siswa}

Pada tahap ini dilaksanakan uji coba secara menyeluruh pada seluruh siswa kelas XI IPS 3 yang berjumlah 30 siswa selama 4 pertemuan dimulai dari tanggal 5 Maret sampai dengan 26 Maret 2021. Pada pertemuan keempat dilakukan proses penilaian kinerja siswa menggunakan isntrumen penilaian kinerja yang telah dikembangkan. Berikut adalah hasil penilaian kinerja siswa menggunakan instrumen penilaian kinerja tersebut. 


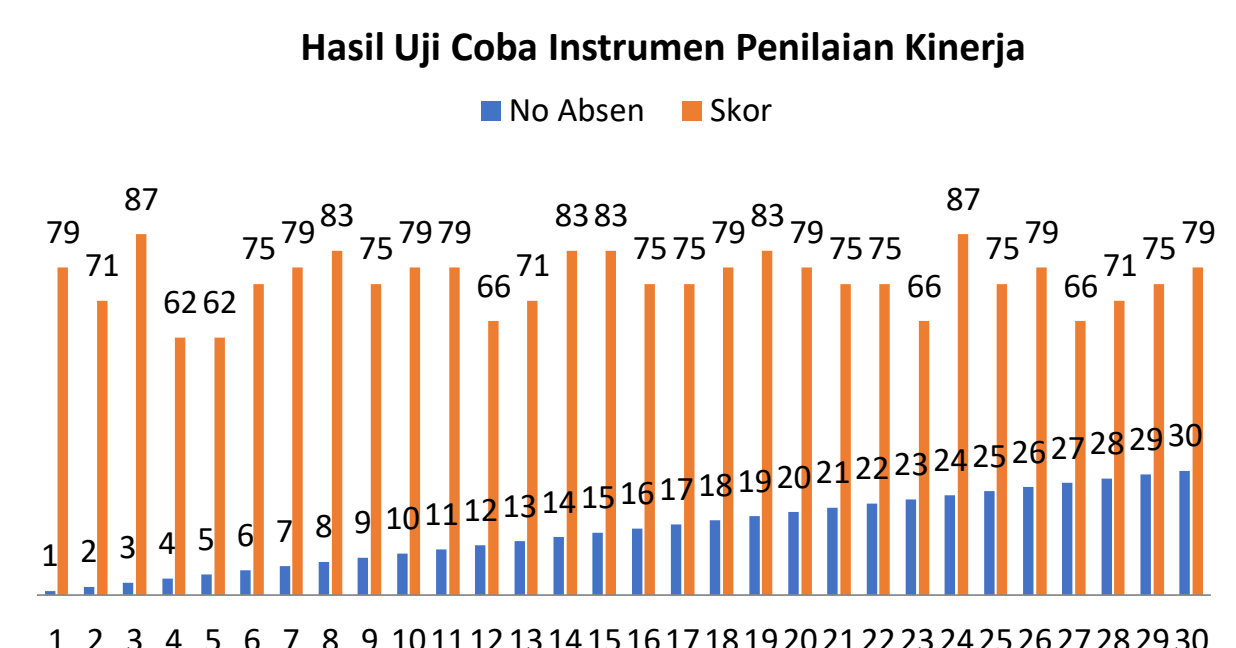

\section{Gambar 2. Nilai Keterampilan Siswa}

Gambar di atas memaparkan distribusi skor penilaian kinerja siswa dalam melakukan penelitian dokumentasi konflik sosial di masyarakat. Skor penilaian ranah keterampilan tersebut dikonversi sesuai dengan panduan penilaian kurikulum 2013. Berikut ini hasil skor yang diperoleh siswa.

\section{Tabel 3. Rekap Predikat Skor Siswa}

\begin{tabular}{cc}
\hline Predikat & Jumlah Siswa \\
\hline A & 2 \\
\hline B & 23 \\
\hline C & 5 \\
\hline
\end{tabular}

Berdasarkan tabel di atas dapat disimpulkan dari 30 orang siswa kelas XI IPS 3 SMA N 2 Lubuk Sikaping 2 orang siswa memperoleh skor dengan predikat A (Sangat Baik), 23 orang siswa memperoleh skor dengan predikat B (Baik) dan 5 orang siswa memperoleh skor dengan predikat $\mathrm{C}$ (Cukup). Jika dipersentasekan, hasil predikat siswa dapat dilihat pada gambar di bawah ini.

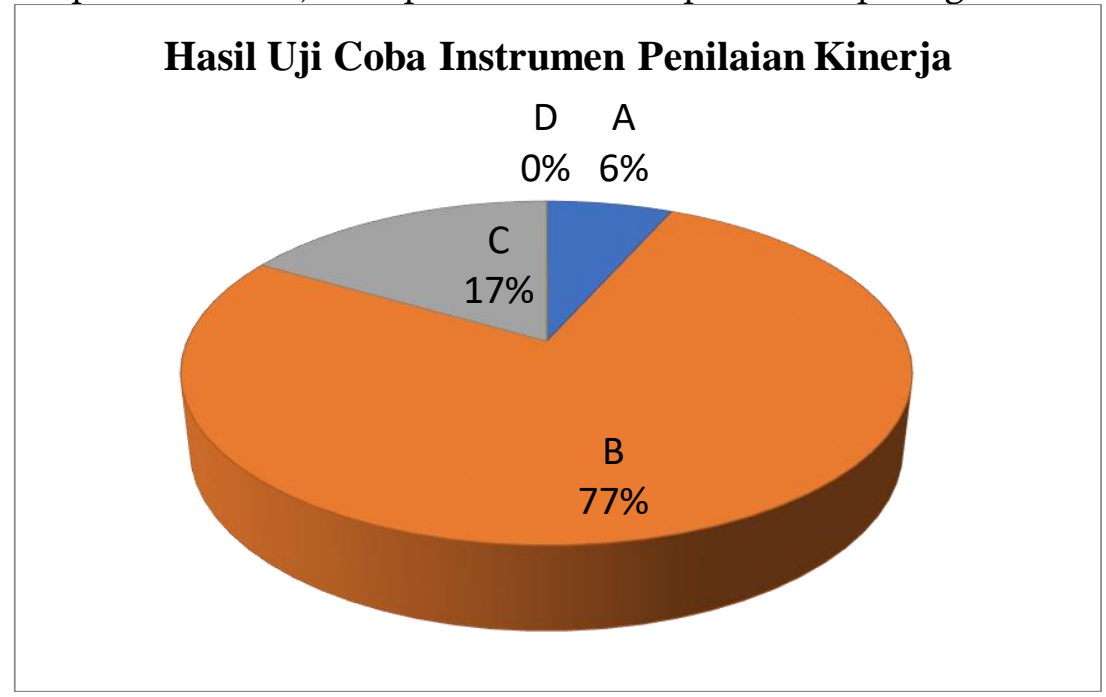

Gambar 4. Persentase Nilai Keterampilan Siswa 
Berdasarkan gambar di atas dapat disimpulkan dari 30 siswa kelas XI IPS 3 sebanyak $6 \%$ siswa memperoleh nilai $\mathrm{A}, 77 \%$ siswa memperoleh nilai $\mathrm{B}, 17 \%$ siswa memperoleh nilai $\mathrm{C}$ dan 0 $\%$ siswa memperoleh nilai $\mathrm{D}$. Hasil yang diperoleh dari uji coba instrumen penilaian kinerja untuk mengukur keterampilan siswa sudah efektif.

Dari hasil penelitian ini dipahami melalui teori konstruktivistik karena konstruktivistik bersifat membangun, membangun dari segi kemampuan, pemahaman, dalam proses pembelajaran. Sebab dengan memiliki sifat membangun maka dapat diharapkan keaktifan dari pada siswa akan meningkat kecerdasannya. Penilaian akan menghasilkan hasil yang akurat jika dilaksanakan menggunakan instrument penilaian yang terukur, valid dan reliabel. Karena penilaian proses maupun belajar hasil belajar tidak hanya mengukur salah satu aspek kemampuan siswa, namun penilaian harus dilakukan secara holistik agar mampu mengukur seluruh aspek kemampuan peserta didik. Domain kognitif, afektif dan psikomotor peserta didik akan dapat berkembang lebih maksimal jika proses pembelajaran dan penilaian dirancang, dilaksanakan dan dievaluasi secara holistik dan berkesinambungan. (Sylvia, Anwar, \& Khairani, 2019). Selain itu pelaksanaan proses penilaian tidak daapt dilepaskan dari proses pembelajaran. Pemilihan model pembelajaran yang sesuai akan mendukung berkembangnya keterampilan siswa. Pemilihan model problem based learning pada penelitian ini merangsang berkembangnya keterampilan siswa. Dengan belajar memecahkan suatu permasalahan siswa akan berusaha untuk menggunakan serta menghubungkan pengetahuan-pengetahuan yang telah dimilikinya. (Argusni \& Sylvia, 2019). Kemampuan pemecahan masalah mengacu pada upaya yang diperlukan siswa dalam menentukan solusi atas masalah yang ada pada artikel konflik sosial yang ditelitinya.

\section{Kesimpulan}

Instrumen penilaian kinerja yang telah dikembangkan meliputi aspek pengumpulan data, analisis data dan komunikasi. Instrumen ini diujicobakan pada pembelajaran sosiologi materi konflik sosial pada kelas XI IPS 3 SMAN 2 Lubuk Sikaping. Jumlah sampel pada penelitian ini adalah 30 orang. Hasil uji efektifitas memperlihatkan 2 orang siswa memperoleh skor penilaian keterampilan dengan predikat A (5\%), 23 orang dengan predikat B $(77 \%)$ dan 5 orang $(17 \%)$ dengan predikat $\mathrm{C}$. Hasil ini memperlihatkan instrumen penilaian kinerja efektif mengukur keteampilan siswa khusunya dalam melakukan penelitian dan mempresentasikan penelitian pada materi konflik sosial.

\section{Daftar Pustaka}

Argusni, R., \& Sylvia, I. (2019). Implementasi Pelaksanaan Model Problem Based Learning Untuk Meningkatkan Kemampuan Problem Solving Siswa Kelas XI IIS SMAN 16 Padang. Jurnal Sikola: Jurnal Kajian Pendidikan Dan Pembelajaran, 1(1), 52-59. https://doi.org/10.24036/sikola.v1i1.9

Arifin, Z. (2009). Evaluasi Pembelajaran. Bandung: PT. Remaja Rosdakarya.

Basri, Q., Syamsudduha, S., \& Taufiq, A. U. (2017). Pengembangan Penilaian Kinerja Teknik Peer Assessment Pada Pembelajaran Biologi Kelas XI di MA Madani Alauddin. Jurnal Biotek, 5(2), 19-36.

Hamid, M. (2017). Panduan Penilaian oleh Pendidik dan Satuan Pendidikan Sekolah Menengah Atas. Jakarta: Kemendikbud.

Kemendikbud. (2013). Permendikbud No 66 Tahun 2013 tentang Standar Penilaian Pendidikan..

Kemendikbud. (2020). Permendikbud No 23 Tahun 2020 Mengenai Standar Penilaian Pendidikan.

Kunandar, K. (2014). Penilaian Autentik (Penilaian Hasil Belajar Peserta Didik Berdasarkan Kurikulum 2013. Jakarta: Raja Grafindo Persada.

Jurnal Sikola: Jurnal Kajian Pendidikan dan Pembelajaran Vol. 2, No. 4, Th. 2021 
Nuareni, S. (2016). Penerapan Model Problem Based Learning dengan Tipe Webbed Untuk Meningkatkan Motivasi dan Hasil Belajar Siswa. Universitas Pasuruan.

Pane, A., \& Darwis Dasopang, M. (2017). Belajar Dan Pembelajaran. FITRAH:Jurnal Kajian IlmuIlmu Keislaman, 3(2), 333. https://doi.org/10.24952/fitrah.v3i2.945

Setyono, B. (2005). Penilaian Outentik dalam Kurikulum Berbasis Kompetensi.

Soerjono, S. (2013). Pengantar Sosiologi. Jakarta: PT Grafindo Persada.

Sugiyono, S. (2017). Metode Penelitian Kuantitatif, Kualitatif, dan R\&D. Jakarta: Alfabeta.

Sylvia, I., Anwar, S., \& Khairani, K. (2019). Pengembangan Instrumen Penilaian Autentik Berbasis Pendekatan Authentic Inquiry Learning Pada Mata Pelajaran Sosiologi di Sekolah Menengah Atas. Socius, 6(2), 103-120. https://doi.org/10.24036/scs.v6i2.162 